\title{
UJI KUAT TEKAN DAYA SERAP AIR DAN MASSA JENIS BATU BATA MERAH BERBAHAN TAMBAHAN ABU KULIT DAN JANGGEL JAGUNG DI WULUHAN JEMBER
}

\author{
${ }^{1)}$ Mei Sofiatul Hasahah, ${ }^{1)}$ Yushardi, ${ }^{1)}$ Albertus Djoko Lesmono \\ 1) Program Studi Pendidikan Fisika FKIP Universitas Jember
}

Email: meisofia872@gmail.com

\begin{abstract}
The increase in Indonesia's development activities increases people's consumption of more quality construction materials and is easy to reach in terms of price. Building materials with good quality can improve the quality of building construction. The increasing need of the community for building materials triggered the development of the brick-making industry. Redbrick is an element of building used in building construction made from clay base material with or without other mixed materials. This research is a type of experimental research. The purpose of this study is to know and analyze the composition of the addition of corn bark ash and ash corn cob appropriately to produce the quality of bricks with high compressive strength, low water absorption, and large density. Additional materials in this study in the form of corn bark ash and ash corn cob. The quality of red bricks is seen from three aspects, namely compressive strength, water absorption, and density. The largest compressive strength was obtained in the addition of ash corn cob by $2.5 \%$ by 37.2 $\mathrm{kg} / \mathrm{cm} 2$ and the compressive strength of $49.5 \mathrm{~kg} / \mathrm{cm}^{2}$ on the addition of corn skin ash by $2.5 \%$. Water absorption measurement of all types of red bricks the results of the study showed all the results of water absorption is not eligible sni. The highest density was obtained from a mixture of $2.5 \%$ ash corn cob material of $17.5 \mathrm{gr} / \mathrm{cm}^{3}$. the best composition to produce bricks with strong compressive value and high density and have low water absorption is $2.5 \%$ addition of ash corn cob and the addition of $2.5 \%$ corn skin ash.
\end{abstract}

Keywords: Red bricks, strong press, water absorption, density.

\section{PENDAHULUAN}

Kebutuhan manusia tidak hanya dalam hal pangan tetapi juga dalam hal sandang dan papan. Papan dimaksudkan pada kebutuhan manusia akan rumah dan tempat berlindung. Kualitas papan yang baik, kuat, serta nyaman dapat menjamin keselamatan dari penghuni rumah. Kuantitas pembangunan gedung semakin tinggi dampak dari semakin besarnya jumlah penduduk di Indonesia. Peningkatan kegiatan pembangunan akan meningkatkan konsumsi masyarakat terhadap bahan kontruksi yang lebih berkualitas dan mudah dijangkau dari segi harga.
Teori geotektonik menyebutkan Indonesia merupakan wilayah dengan aktivitas seperti pembentukan pegunungan, peristiwa vulkanisme, getaran gempa bumi sehingga tidak stabil. Keadaan geotektonik Indonesia menjadikan Indonesia sebagai negara rawan terjadi gempa bumi. Kerusakan akibat gempa terjadi pada bangunan sederhana seperti rumah sederhana 1 tingkat dan 2 tingkat (Sehonada et al, 2013). Gempa bumi dapat mengakibatkan banyak kerugian dan kerusakan utamanya pada bangunan. Gempa bumi di Indonesia menuntut perkembangan konstruksi yang memadai. Bahan bangunan dengan 
kualitas baik dapat meningkatkan kualitas konstruksi bangunan. Arman dan Setiawan (2019) menyebutkan bahwa kualitas bahan dapat dilihat dari segi daya tahan, daya serap air serta memenuhi spesifikasi teknis.

Bangunan di Indonesia secara sederhana terdiri atas dinding, atap, pondasi dan lantai. Dinding merupakan komponen penyusun bangunan paling besar. Dinding tersusun dari beberapa jenis bahan seperti batako, bata ringan, atau batu bata merah namun, batu bata merah lebih banyak digunakan masyarakat sebagai bahan membangun dinding. Penggunaan batu bata merah dikarenakan harga yang relatif terjangkau. Pambudi dan Hepiyanto (2019) menyebutkan bahwa batu bata paling banyak digunakan dengan pertimbangan cukup kuat, ekonomis, efisien, mudah didapat, serta bahan baku pembuatannya mudah diperoleh.

Pengguna batu bata merah bukan hanya dari kalangan masyarakat pedesaan namun juga masyarakat kota. Peningkatan kebutuhan masyarakat akan bahan bangunan memicu perkembangan industri pembuatan batu bata. Maturnus (2010) menuliskan bahwa industri pembuatan batu bata merupakan usaha yang berkembang dengan cepat. Perkembangan industri batu bata meliputi peningkatan dari segi kualitatif maupun kuantitatif. Peningkatan secara kualitatif dilakukan dengan inovasi menciptakan batu bata dengan mutu tinggi yang lebih tahan gempa. Pemanfaatan bahan bahan yang terbuang percuma di lingkungan dapat meningkatkan kualitas batu bata sekaligus meningkatkan pendapatan pengrajin.

Batu bata merah adalah suatu unsur bangunan yang digunakan pada konstruksi bangunan dibuat dari bahan dasar tanah liat dengan atau tanpa bahan campuran lain (Handayani, 2010). Jenis batu bata di Indonesia tergolong lumayan beragam seperti batako, bata merah, bataton, dan bata ringan. Bata merah paling banyak digunakan oleh masyarakat dengan bahan dasar tanah liat yang dicetak secara manual (Rahman et al., 2016).

Bata merah merupakan salah satu jenis batu bata yang dijemur dan dibakar dengan bahan dasar lempung. Lempung yaitu koloid dengan ukuran kurang dari satu mikron. Koloid terlihat seperti lempengan lempengan kecil yang berisi lembaran-lembaran kristal. Bata merah dibuat dengan mencampurkan lempung dengan air sebagai pengikat material. Penambahan air memudahkan batu bata dicetak (Andayono et al., 2019). Syarat air yang baik ditambahkan kedalam adonan adalah air cukup bersih, tidak mengandung garam serta tidak sadah (Febriani, 2012).

Bahan tambahan pada penelitian ini berupa abu kulit jagung dan abu janggel jagung. Abu kulit jagung merupakan hasil dari pembakaran kulit jagung. Tahap pertama pembuatan abu adalah pemotongan kulit jagung. Kemudian kulit jagung dicuci untuk menghilangkan kotoran, pasir dan tanah dan dikeringkan dengan cara dijemur. Kulit jagung yang sudah kering dibakar selama 4 jam hingga berubah jadi abu kulit jagung (Larasati et al., 2018). Abu janggel jagung merupakan hasil dari pembakaran janggel jagung kering hingga menjadi bentuk abu sehingga mudah untuk dicampurkan kedalam adonan batu bata merah.

Pengujian terhadap kualitas 
batu-bata merah dengan campuran Abu janggel jagung dan abu kulit jagung harus memenuhi syarat-syarat batu bata merah. Batu bata harus memiliki rusuk yang siku dan tajam. Bidang sisi batu bata harus datar dan tidak menunjukkan retak-retak. Batu-bata tidak mudah hancur atau patah, memiliki warna seragam dan memiliki bunyi yang nyaring saat dipukul. Ukuran standar batu-bata merah yaitu batu bata merah dengan panjang 230-240 mm, lebar 110-115 mm, tebal 50-52 mm.

Kualitas batu bata merah dapat dilihat dari tiga aspek yakni kuat tekan, daya serap air, dan massa jenis. Kuat tekan batu bata merupakan kemampuan maksimum dari pekerjaan pasangan batu bata dengan mortar. Kuat tekan dinding pasangan batu bata lebih banyak dipengaruhi oleh kekuatan mortar dan dibatasi kekuatan batu bata. Standar kuat tekan yang disyaratkan oleh SNI 15-20942000 ditunjukkan oleh persamaan berikut:

$$
P=\frac{F}{A}
$$

Keterangan :

$\mathrm{P}=$ kuat Tekan $\left(\mathrm{kg} / \mathrm{cm}^{2}\right)$

$\mathrm{F}=$ Beban yang diberikan $(\mathrm{kg})$

$\mathrm{A}=$ Luas Penampang $\left(\mathrm{cm}^{2}\right)$

Daya serap air merupakan kemampuan suatu bahan dalam menyerap air. Daya serap yang tinggi akan berpengaruh pada pemasangan batu bata dan adukan karena air. Adukan yang sudah jadi akan diserap oleh batu-bata sehingga pengeras adukan tidak berfungsi dan berakibat pada kuat adukan menjadi lemah. Daya serap tinggi akibat dari kadar pori pada batu-bata yang besar (Handayani,
2010). Standar Nasional Indonesia (SNI) mensyaratkan penyerapan air maksimum dari batu bata merah pejal untuk digunakan pada dinding yang diizinkan adalah 20\%. Persamaan dalam menghitung penyerapan air batu bata ditunjukkan oleh persamaan berikut:

$$
\% \text { Penyerapan }=\frac{100(M s-M d)}{M d}(\%)
$$

Keterangan :

$\mathrm{Md}=$ Massa batu bata kering $(\mathrm{kg})$

Ms = Massa jenuh batu bata setelah direndam dalam air dingin $(\mathrm{kg})$

Massa jenis merupakan massa yang terdapat dalam satu satuan volume. Massa jenis disebut juga dengan rapat bahan. Massa jenis yang diisyaratkan untuk digunakan adalah 1.60-2.50 $\mathrm{gr} / \mathrm{cm}^{3}$. Persamaan menghitung densitas adalah sebagai berikut:

$$
\rho=\frac{m}{V}
$$

Keterangan :

$\rho=$ Densitas Bahan $\left(\mathrm{gr} / \mathrm{cm}^{3}\right)$

$\mathrm{m}=$ Massa kering bahan (gr)

$\mathrm{V}=$ Volume bahan $\left(\mathrm{cm}^{3}\right)$

(Pramono dan Adi, 2014).

\section{METODE PENELITIAN}

Penelitian ini merupakan penelitian jenis eksperimen. Tujuan dari penelitian ini adalah mengetahui dan menganalisis komposisi penambahan abu kulit jagung dan abu janggel jagung yang tepat untuk menghasilkan kualitas batu bata dengan kuat tekan tinggi, daya serap air rendah, dan massa jenis besar. Penelitian dilaksanakan dengan tahapan 1) 
persiapan bahan uji, (2) Pembuatan batu bata merah secara manual dengan penambahan abu janggel jagung sebesar 2,5\%, 5\%, 7,5\%, dan $10 \%$. Penambahan abu kulit jagung sebesar $2,5 \%, 5 \%, 7,5 \%$, dan $10 \%$ serta penambahan $5 \%$ abu janggel jagung dan 5\% abu kulit jagung secara bersamaan (3) Pengeringan batu bata merah (4) pembakaran batu bata merah (5) pengujian kuat tekan dengan Universal Testing Machine (UTM) digital, pengujian massa jenis dan daya serap air (6) pengolahan data penelitian, (7) penarikan kesimpulan.

Pembuatan batu bata merah dilaksanakan di desa Tamansari kecamatan Wuluhan Kabupaten Jember. Pengujian batu bata merah dilakukan di dua tempat berbeda yakni di laboratorium fisika dasar prodi pendidikan fisika untuk menguji daya serap air dan massa jenis dan di laboratorium struktur dan material konstruksi, Fakultas Teknik, Universitas Jember untuk menguji kuat tekan.

Pengambilan data dilakukan sebanyak tiga kali pada masing masing batu bata merah dan masing-masing variabel. Data yang diperoleh merupakan data mentah berupa tekanan yang bisa ditanggung oleh batu bata merah dengan luas tertentu. Uji daya serap air memperoleh data dengan menimbang massa batu bata dalam keadaan basah dan kering. Data yang diperoleh berupa massa kering dan massa basah masing-masing batu bata dalam satuan kilogram. Uji massa jenis memperoleh data dengan cara penimbangan massa dan pengukuran volume batu bata. data yang diperoleh untuk uji massa jenis berupa massa dan volume.
Data yang didapat dianalisis dan diambil rata rata dari data hasil analisis. Hasil analisis data ditampilkan dalam bentuk tabel dan diagram batang. Grafik menunjukkan hubungan antara komposisi campuran terhadap masingmasing variabel.

\section{HASIL DAN PEMBAHASAN}

Batu bata merah merupakan suatu unsur bangunan dalam pembuatan konstruksi bangunan yang terbuat dari campuran tanah lempung dan air dengan atau tanpa tambahan bahan campuran lain (Ramli, 2007). Batu bata merah hasil penelitian ini berbentuk balok dengan ukuran panjang $20 \mathrm{~cm}$, lebar $12 \mathrm{~cm}$ dan tinggi $5 \mathrm{~cm}$. Batu bata merah yang diuji dipotong menjadi bentuk kubus dengan ukuran panjang lebar dan tinggi sama yaitu $5 \mathrm{~cm}$. Berikut gambar batu bata hasil penelitian :

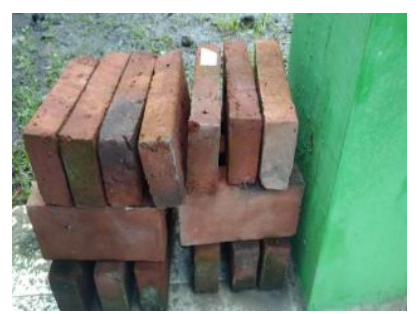

Gambar 1. Batu bata sebelum dipotong

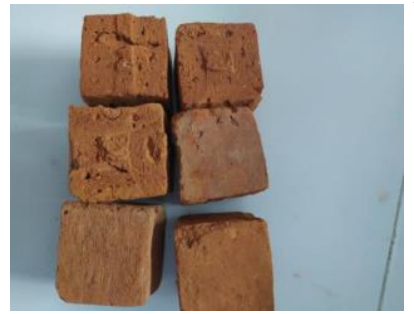

Gambar 2. Batu bata merah setelah dipotong tampak atas

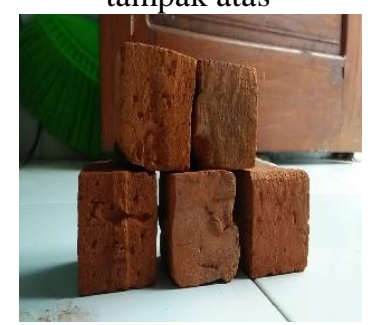


Gambar 3. Batu bata merah setelah dipotong tampak samping

hasil analisis data penelitian sebagai berikut:

Tabel 1. Data Hasil Penelitian

\begin{tabular}{lcccc}
\hline & $\begin{array}{c}\text { Jenis } \\
\text { batu bata } \\
\text { merah }\end{array}$ & $\begin{array}{c}\text { Kuat } \\
\text { Tekan } \\
\left(\mathrm{kg} / \mathrm{cm}^{2}\right)\end{array}$ & $\begin{array}{c}\text { Daya } \\
\text { Serap } \\
\text { Air } \\
(\%)\end{array}$ & $\begin{array}{c}\text { Massa } \\
\text { Jenis } \\
\left(\mathrm{gr} / \mathrm{cm}^{3}\right)\end{array}$ \\
\hline 1 & $\mathrm{~J}_{1}$ & 37,2 & 26,5 & 1,751 \\
\hline 2 & $\mathrm{~J}_{2}$ & 33,1 & 25,7 & 1,673 \\
\hline 3 & $\mathrm{~J}_{3}$ & 29,8 & 25,3 & 1,663 \\
\hline 4 & $\mathrm{~J}_{4}$ & 24,6 & 25,8 & 1,595 \\
\hline 5 & $\mathrm{~K}_{1}$ & 49,5 & 23,6 & 1,694 \\
\hline 6 & $\mathrm{~K}_{2}$ & 27,3 & 24,3 & 1,539 \\
\hline 7 & $\mathrm{~K}_{3}$ & 36,8 & 27,3 & 1,533 \\
\hline 8 & $\mathrm{~K}_{4}$ & 31,2 & 23,9 & 1,518 \\
\hline 9 & $\mathrm{~B}$ & 26,3 & 26,2 & 1,546 \\
\hline 10 & $\mathrm{JK}$ & 31,5 & 26,5 & 1,560 \\
\hline $\mathrm{Keterangan}$ & & & \\
\hline
\end{tabular}

Keterangan :

a. $\mathrm{J}_{1}$ : Campuran $2,5 \%$ abu janggel jagung

b. $\mathrm{J}_{2}$ : Campuran $5 \%$ abu janggel jagung

c. $\mathrm{J}_{3}$ : Campuran $7,5 \%$ abu janggel jagung

d. $\mathrm{J}_{4}$ : Campuran $10 \%$ abu janggel jagung

e. $\mathrm{K}_{1}$ : Campuran $2,5 \%$ abu kulit jagung

f. $\mathrm{K}_{2}$ : Campuran $5 \%$ abu kulit jagung

g. $\mathrm{K}_{3}$ : Campuran $7,5 \%$ abu kulit jagung

h. $\mathrm{K}_{4}$ : Campuran $10 \%$ abu kulit jagung

i. B : Batu-bata merah tanpa campuran j. JK : Batu-bata merah dengan campuran 5\% abu kulit dan 5\% abu janggel jagung

Kuat tekan batu bata merah merupakan besarnya beban persatuan luas yang bisa mengakibatkan batu bata merah atau benda uji hancur bila diberi beban dengn gaya tekan tertentu (Rahman et al.,2016). Semakin besar nilai kuat tekan yang dihasilkan menunjukkan semakin bagus kualitas dari suatu bahan yang dalam hal ini adalah batu bata merah. Hasil kuat tekan ditampilkan dalam grafik sebagai berikut :

\section{Grafik Data Kuat Tekan}

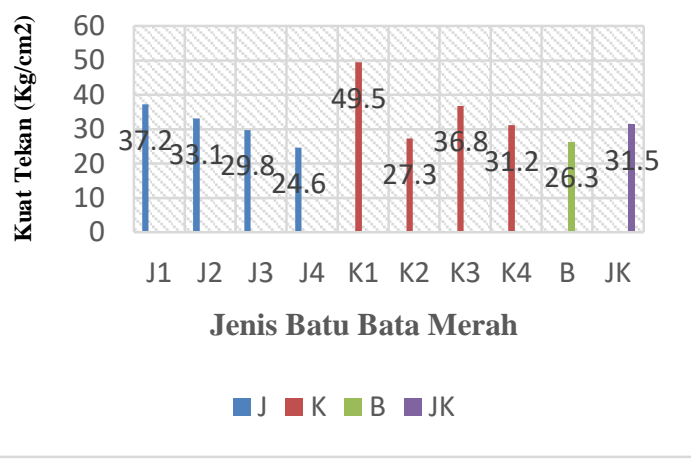

Gambar 4. Grafik Kuat Tekan Batubata Merah

Tabel menunjukkan nilai kuat tekan terbesar yang diperoleh pada penambahan abu janggel jagung sebesar $2,5 \%$ sebesar $37,2 \mathrm{~kg} / \mathrm{cm}^{2}$. Nilai kuat tekan semakin turun seiring dengan bertambahnya bahan campuran. Grafik menunjukkan Hasil kuat tekan batu bata berbahan tambahan abu janggel jagung lebih besar dibandingkan batu bata merah biasa. Kandungan silika pada janggel jagung tergolong tinggi yaitu sebesar 29\% (Almachzuuni et al., 2020). Silika atau $\mathrm{SiO}_{2}$ dapat mempengaruhi reaksi pengerasan pada suatu bahan sehingga didapat kuat tekan suatu bahan 
meningkat (Nadia dan Fauzi, 2011). Penurunan nilai kuat tekan akibat Penambahan abu janggel jagung yang mengandung silika yang juga terkandung pada Fly Ash atau biosolid terlalu banyak membuat batu bata menjadi sulit untuk dipadatkan sehingga menghasilkan nilai kuat tekan dari suatu produk menjadi menurun.

Nilai kuat tekan batu bata merah berbahan tambahan abu kulit jagung paling tinggi sebesar $49,5 \mathrm{~kg} / \mathrm{cm}^{2}$ pada campuran abu kulit jagung sebesar 2,5\%. Nilai kuat tekan hasil pencampuran abu kulit jagung tidak stabil karena pada penambahan sebesar $5 \%$ mengalami penurunan kuat tekan namun kembali meningkat pada penambahan $7,5 \%$ dan kembali mengalami penurunan pada penambahan $10 \%$.

Grafik menunjukkan nilai kuat tekan hasil penambahan abu kulit jagung lebih besar dibandingkan nilai kuat tekan hasil penambahan abu janggel jagung dan kuat tekan batu bata merah tanpa bahan tambahan. Penambahan abu kulit jagung meningkatkan hasil kuat tekan lebih baik dibandingkan abu janggel jagung. Hasil kuat tekan pada semua persentase memenuhi kuat tekan yang disyaratkan oleh SII. Hasil menunjukkan $\mathrm{J}_{1}$ paling unggul pada nilai kuat tekan dibandingkan batu bata jenis lain sebesar $49,5 \mathrm{~kg} / \mathrm{cm}^{2}$.

Variabel kedua yang ingin diketahui pada penelitian ini adalah daya serap air. Hasil daya serap air ditampilkan dalam grafik sebagai berikut :

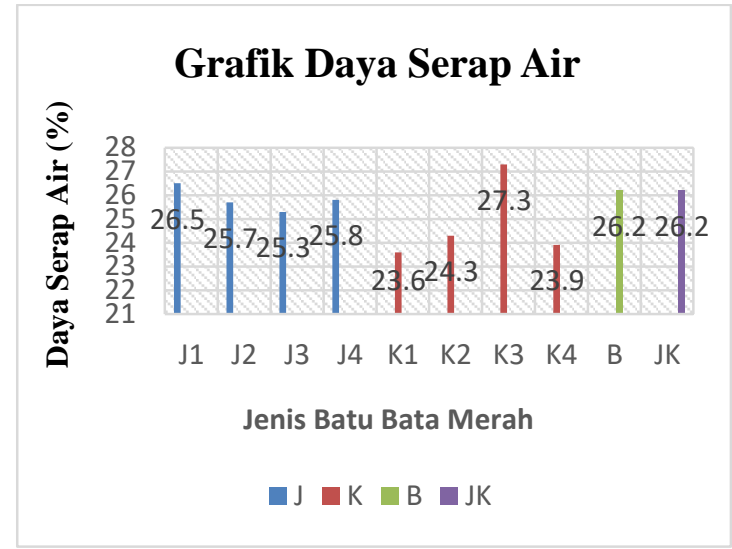

Gambar 4. Grafik Daya Serap Air Batu-bata Merah

Daya serap air batu bata merah didefinisikan sebagai kemampuan batu bata merah dalam menyerap air. SNI atau Standar Nasional Indonesia mensyaratkan daya serap air yang diperbolehkan pada batu bata merah sebesar $20 \%$. pengukuran daya serap air semua jenis batu bata merah hasil penelitian menunjukkan seluruh hasil daya serap air tidak memenuhi syarat SNI.

Grafik menunjukkan daya serap air yang semakin menurun pada penambahan abu janggel jagung tetapi tidak terlalu signifikan hal ini dapat terjadi karena jumlah abu janggel jagung yang ditambahkan tidak memiliki perbedaan yang signifikan pada masing masing persentase. Penurunan nilai daya serap air menunjukkan pori pori didalam batu bata diisi oleh abu janggel jagung. Kandungan silika pada abu janggel jagung sebesar $29,7 \%$ berfungsi sebagai pengikat material campuran. Semakin banyak abu janggel jagung yang ditambahkan maka semakin sedikit rongga sehingga daya serap air semakin kecil.

Penambahan abu kulit jagung menunjukkan grafik hasil daya serap air 
mengalami penurunan pada campuran bahan 2,5\% mengalami kenaikan sampai campuran bahan sebesar 7,5\% lalu mengalami penurunan pada persentase $10 \%$. Hasil daya serap air yang ditunjukkan terlihat tidak stabil sama dengan grafik dari hasil uji kuat tekan. Nilai daya serap air juga dipengaruhi oleh retakan pada batu bata, jadi sangat perlu untuk menjaga batu bata merah dalam kondisi bagus.

Variabel ketiga yang dilihat pada penelitian ini adalah massa jenis batu bata merah. Hasil massa jenis ditampilkan dalam grafik sebagai berikut :

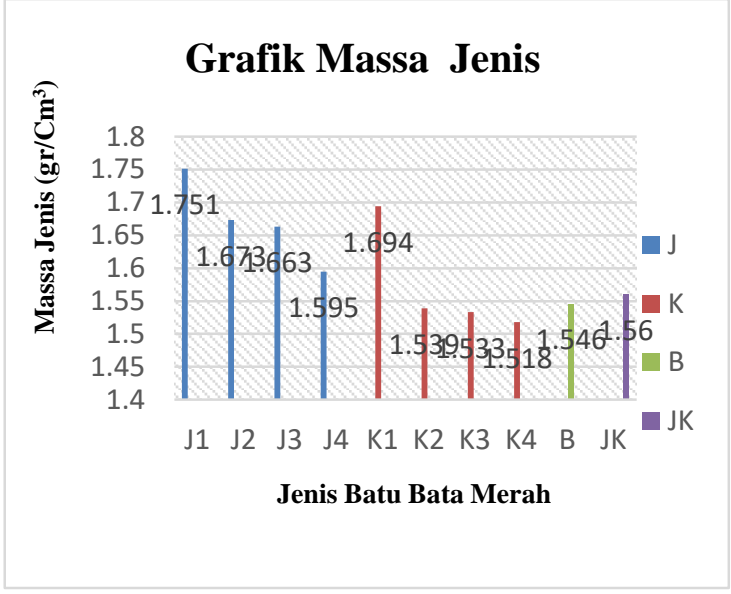

Gambar 4. Grafik Massa Jenis Batu-bata Merah

Hasil massa jenis menunjukkan nilai sesuai syarat dari SNI yaitu antara $1,6-2,5 \mathrm{gr} / \mathrm{cm}^{3}$. Grafik menunjukkan massa jenis tertinggi didapat dari campuran $2,5 \%$ bahan abu janggel jagung yaitu sebesar $17,5 \mathrm{gr} / \mathrm{cm}^{3}$ lalu mengalami penurunan hingga campuran $10 \%$ mencapai batas minimum batu bata SNI yaitu 1,595 $\mathrm{gr} / \mathrm{cm}^{3}$. Massa jenis batu bata merah jenis ini lebih besar dari batu bata merah biasa. Penurunan massa jenis ini linear dengan semakin menurunnya nilai kuat tekan batu bata merah. Massa jenis batu bata merah berbahan abu kulit jagung menunjukkan massa jenis paling tinggi diperoleh pada campuran $2,5 \%$.

Batu bata JK merupakan batu bata dengan bahan campuran 5\% abu kulit jagung dan 5\% abu janggel jagung. Batu bata ini dibuat dengan tujuan sebagai pembanding. Hasil penelitian menunjukkan batu bata memiliki nilai kuat tekan cukup tinggi namun juga memiliki nilai daya serap air yang tinggi sehingga batu bata JK tidak disarankan untuk diproduksi.

Hubungan antara kuat tekan daya serap air dan massa jenis adalah semakin tinggi nilai kuat tekan semakin besar massa jenis sehingga kemampuan daya serap air semakin menurun. Hasil analisis data dari keseluruhan batu bata merah dapat disimpulkan komposisi paling baik untuk menghasilkan batu bata dengan nilai kuat tekan dan massa jenis yang tinggi serta memiliki daya serap air yang rendah adalah sebesar 2,5\% penambahan abu janggel jagung dan penambahan 2,5\% abu kulit jagung. Penambahan bahan abu kulit jagung dan abu janggel jagung terbukti meningkatkan kualitas batu bata merah tanpa harus menambah biaya produksi sehingga dapat meningkatkan pendapatan pengrajin.

\section{DAFTAR PUSTAKA}

Almachzuuni, K., W. Warsito., dan E. Noerhayati. 2020. Pengaruh Penambahan Variasi Abu Janggel Jagung dengan Serat Bambu Terhadap Uji Kuat Tarik Belah. Malang. Jurnal Rekayasa Sipil. 8(8) : 1-11

Andayono, T., E. Juliafad., dan R. Halim. 2019. Karakteristik batu 
bata campuran hasil sedimentasi penambangan batu gamping area 412,3 ha bukit tajarang. Padang. Jurnal Inovasi Vokasional dan Teknologi. 19(1).

Arman. A.STT., MT. dan A. Setiawan. 2019. Study Eksperimen Pengaruh Campuran SIKA LN dalam Meningkatkan Kuat Tekan Bata Beton Ringan. Padang. Jurnal Teknik. 2(1): 16120.

Febriani, E. 2012. Pengaruh Penggantian Sebagian Tanah Liat dengan Abu Sekam Padi dan Lama Pembakaran Terhadap Karakteristik Fisis dan Mekanik Batu Bata. Skripsi. Surakarta: Fakultas Keguruan dan Ilmu Pendidikan Universitas Sebelas Maret.

Handayani, S. 2010. Kualitas Batu-Bata Dengan Penambahan Serbuk Gergaji. Jurnal Teknik Sipil Dan Perencanaan. 12(1): 4150 .

Larasati, R., S. Haryani, dan E. Budi. 2018. Serbuk Kulit Jagung untuk Menurunkan Kadar COD dan BOD Air Sumur Gali. Semarang. Indonesian Journal of Chemical Science. 7(1) : 5-10.

Maturnus, I. 2010. Analisis Pendapatan Usaha Batu Bata. Jurnal EKOMEN. 10(1) :67-73.

Nadia, M.T dan A. Fauzi. 2011. Pengaruh Kadar Silika Pada Agregat Halus Campuran Beton
Terhadap Peningkatan Kuat Tekan. Jakarta. Jurnal Konstruksia. 3(1) : 35-43.

Pambudi, A.K.A., dan R. Hepiyanto. 2019. Perbandingan Biaya Pelaksanaan Pekerjaan Dinding Menggunakan Bata Ringan dan Bata Merah pada Perumahan Type 36. Lamongan. Jurnal Teknik Sipil Universitas Islam Lamongan. 4(1) : 238-247.

Pramono., dan S, Adi. 2014. Sampah Sebagai Bahan Baku Pembuatan Batu Bata. Prosiding Semnas Enterpreneurship. Universitas Wijayakusuma Purwokerto. Purwokerto.

Rahman, H.A., Wisnumurti, dan A. Zacoeb. 2016. Uji Kuat Tekan Bata Merah menggunakan Mortar Pasir Kwarsa. Malang. Jurnal Teknik Sipil. 1(2) : 1-13.

Ramli.2007. Pengaruh pemberian material limbah serat alami terhadap sifat fisika bata merah. Skripsi. Sumatera Barat: Fakultas MIPA Universitas Negeri Padang.

Sehonada, O., B.M.M. Ointu, J.Winny, dan R.R. Pandeleke. 2013. Kajian Uji Laboratorium Nilai Modulus Elastisitas Bata Merah dalam Sumbangan Kekakuan pada Struktur Sederhana. Manado. Jurnal Sipil Statik. 1(12) : 797800 